Pobrane z czasopisma Annales H - Oeconomia http://oeconomia.annales.umcs.pl Data: 26/04/2023 12:41:34

DOI:10.17951/h.2017.51.2.69

\begin{tabular}{lcl}
\hline \multicolumn{2}{c}{ A N N A L E S } \\
UNIVERSITATIS MARIAE CURIE-SKŁODOWSKA \\
LUBLIN - POLONIA \\
VOL.LI, 2 & SECTIOH \\
\hline
\end{tabular}

Koszalin University of Technology, Faculty of Economic Sciences

JOANNA DYCZKOWSKA

jdyczkowska@wp.pl

\title{
Marketing of Logistics Services in Poland and Germany
}

Marketing usług logistycznych w Polsce i Niemczech

Key words: marketing; logistics service; marketing instruments

Słowa kluczowe: marketing; usługi logistyczne; instrumenty marketingu

JEL codes: M31; M12; L91

\section{Introduction}

A special role is attributed to the TSL (transport-shipping-logistics) market because its services guarantee the development of the economy of the whole state in individual branches and enterprises. Marketing activities pursued by TSL companies and logistics operators provide institutional and individual customers with logistics services on the highest level with an additional value and satisfaction. The purpose of the article is an analysis of the development of marketing activities and instruments on the market of logistics services in Poland and Germany as well as an implementation of the elements of marketing-mix. In the article, a comparative analysis method of the services offered and the image created by logistic operators was used. Additionally, an analysis of source literature was conducted. 


\section{Market of TSL services}

The growing international trade exchange and a high level of foreign investments create excellent prospects for the development of the Polish market of transport and logistics services. The role of the Central and Eastern European region is growing as a place of the location of production plants by European companies; Poland, owing to its significance in the region and its geographical situation, should be one of the largest beneficiaries of this tendency. At present, a permanent increase of the supply of logistics services is being observed. This is mainly caused by an increased demand for transport services with a growing range that includes storage of commodities and by a complex of formal and legal activities [Gołembska 2010, p. 268]. An abrupt development of services in the $21^{\text {st }}$ century can be described taking into consideration three factors at least. Firstly, there is a systematic increase of leisure time as a result of the automation of production processes in the world. The second factor is the overwhelming computer revolution owing to which one may quickly communicate with customers from other states. The third factor, which is induced by the second factor, i.e. the use of computer technologies, is a significant diversification of the forms of the provision of services and an increase of their quality, caused by fast recognition of the size and structure of the demand in the whole world [Gołembska et al. 2008, pp. 9-10]. Companies that operate on the TSL market frequently provide several types of services, e.g. a transport company may also provide storing services, or a forwarding company extends its offer to include customs services [Ciesielski 2005, pp. 57-69].

In 2015, revenues from the sale of services in all transport entities were higher by $4.9 \%$ in comparison with 2014 and amounted to PLN 187.6 billion (increased by $1.8 \%$ in the public sector and by $5.5 \%$ in the private sector) [Transport... 2016, p. 62]. As regards freight shipment by road transport in the European Union in the year 2014, Poland is on the fourth position in the transport of goods in the amount of 1,300,382 thousand tons following Germany (3,052,682 thousand tons), France (1,918,572 thousand tons), Great Britain (1,507,266 thousand tons) and followed by Spain $(1,284,586$ thousand tons).

Germany transports $21.72 \%$ of all freights, and Poland has a participation of $9.25 \%$ in the transports of goods. The five of the highest ranked states have a contribution of $64.5 \%$ in freights transported by road transport. Two countries: Germany as the country with the highest index and Poland as the state under analysis were accepted in further study.

\section{Instruments of logistics services marketing}

The logistics product is a set of customer expectations and requirements as to the good or service in an appropriate form and quality, and which can be realized in accordance with these requirements in the logistics system only. The idea of the 
logistics product is its formation in cooperation with the customer, creation in the "customer's presence" in a desirable form, shape and quality in relation both to goods and services [Gołembska 2009, p. 27]. The presentation of the comprehensive logistics service range emphasizes the significance and value of each of the components. Benefits achieved on the level of basic services are supplemented with further benefits from subsequent levels, which reflects the scope of the logistics operator's activities in relation to the services provided to institutional and individual customers. Service companies that provide logistics services undertake activities connected with an increase of the degree of complexity and diversification of the services offered.

Promotion serves the purpose of exerting influence on customers and potential purchasers. As a result of the use of a specific combination of promotional activities and measures, TSL companies may pass to other market participants information on their own operations (transport, storage) and an offer of comprehensive logistics services, they may satisfy and create purchasers' needs (deliveries in a given time interval) as well as stimulate and orientate the demand for the services offered (charging payment for the commodity). TSL companies, when occurring as the senders of promotional message, build desirable relations with the environment and build their positive image on the market of services [Żurawik and Żurawik 1996, p. 183]. The detailed objectives of the promotional activities of TSL companies are individually diversified and they require a proper configuration of the instruments of promotion.

The standards of customer service related to comprehensive and competitive after-sales services, which include maintenance and warranty services as well as continuous contact with the customer, are of a significance in the sphere of distribution. Interest in the logistics of distribution on the part of managers results from the need to reduce relatively high costs of distribution in connection with the growing competition and the decreasing profitability of companies as well as the possibility to obtain competitive advantage through an increase of customer service standards and product service standards.

The determination of the appropriate price decides about the income of the TSL company, and it is also an important index of the value of customer services and the means to build the image of the company and its products. The special significance of prices in the sector of logistics services follows from the intangible nature of products offered by TSL companies. Logistics companies are oriented onto providing services to companies (B2B), and they will not achieve a success in the sale of high quality services that are tailored to customer needs while offering low prices. In the process of establishing and changing prices, TSL companies take into consideration customer reactions to the relations between the structure of service properties and their quality and price.

The recognition of the process nature of human resources management means that the TSL company must possess personnel with appropriate competences (knowl- 
edge, abilities, experience, openness to cooperation with people, empathy, an acceptation of the system of the company's values, behaviors, ethics and culture towards the environment) required to realize the processes that occur in it [Dyczkowska 2014, p. 110]. Organizations assess logistics above all on the grounds of the three criteria: the ability of linear (operational) management, the problem solving ability and the project management ability [Byrne and Markham 1991, p. 148].

The key role in customer service is attributed to logistics processes in order to satisfy permanently changing needs and expectations. An efficient logistics process allows one to gain competitive advantage over other TSL companies. A provision of a logistics service may vary considering the primary division of service products: parcels, single goods and partial freights in the case of land transport on the territory of the state, the transport of loading units, i.e. containers, in inter-modal transport. In the service of shipment or a logistics service, according to the criterion, Lovelock [1996, p. 30] distinguishes the service process as the one related to the consumer's property. It does not require much involvement on the part of customers in the process of their provision.

To ensure the required quality level of logistics services, each TSL organization develops a management system which is oriented onto pro-quality activities. The effectiveness of the functioning of the system depends on numerous factors, such as: the size of the organization, customer requirements, competition on the market, management of directors and employees. The company designs a quality management system and improves it in the course of the realization of processes [Łunarski 2009, p. 26].

\section{Comparative analysis of logistics services marketing}

The globalization of logistics services is characterized by a reduction in the production cycle time through an introduction of changes to the logistics of supplies, production and distribution logistics. Local companies use the services of external companies based on outsourcing to provide products to customers on the territory of Poland and Germany. These are frequently the same companies. At present, more and more significance is attached to intangible resources including the suppliers of logistics services, who have an influence on the company's final value, and they are often perceived by logistics operators through the prism of the service of consignees. Two logistics operators that offer their services on the territory of Poland and Germany: DP DHL and DB Schenker were covered by the analysis. Table 1 presents the instruments of marketing for both of these capital groups on the territories of Poland and Germany. 
Table 1. Instruments of logistics services marketing for the selected logistics operators that provide services in Poland and Germany

\begin{tabular}{|c|c|c|}
\hline Instrument & Poland & Germany \\
\hline Product & $\begin{array}{l}\text { In the case of DB Schenker, general cargo } \\
\text { transports are proposed in the first order, full } \\
\text { truck and partial transports in the second order, } \\
\text { and parcels in the third order. } \\
\text { DP DHL offers courier consignments, interna- } \\
\text { tional transport in the second order, and storage } \\
\text { in the third order. }\end{array}$ & $\begin{array}{l}\text { In Germany, rail transport is a priority, international } \\
\text { transport realized by air and sea in the second order, } \\
\text { and delivery chain management comes last. } \\
\text { DP DHL offers postal consignments and parcels in } \\
\text { the first order, and then international transport, main- } \\
\text { ly air transport and entering the e-commerce market. }\end{array}$ \\
\hline Promotion & $\begin{array}{l}\text { The main activities: personal sales in the B2B } \\
\text { sector and public relations. } \\
\text { Activities in the area of social responsibility } \\
\text { policy. }\end{array}$ & $\begin{array}{l}\text { DB Schenker mainly pursues activities towards } \\
\text { global solutions and entering new markets: creation } \\
\text { of the Global Land Transport entity. } \\
\text { DP DHL as one of the few pursue activities on B2C } \\
\text { market; hence, advertising in media and the use of } \\
\text { the public relations instrument. }\end{array}$ \\
\hline Distribution & $\begin{array}{l}\text { Systems to satisfy the needs of national cus- } \\
\text { tomers: building of logistics centers and re- } \\
\text { gional terminals and the connection of land } \\
\text { transport systems with international transport } \\
\text { in DB Schenker: with marine and rail transport, } \\
\text { and in DP DHL with air transport. }\end{array}$ & $\begin{array}{l}\text { DP DHL is the national operator of German mail, } \\
\text { and DB Schenker is responsible in } 90 \% \text { for the trans- } \\
\text { port of goods by German rail. } \\
\text { DHL is present in } 220 \text { countries with a fleet in the } \\
\text { airport in Frankfurt. } \\
\text { DB Schenker: as an operator in the seaport in Ham- } \\
\text { burg with container handling for East Europe. }\end{array}$ \\
\hline Price & $\begin{array}{l}\text { DB Schenker-prices for customers from Po- } \\
\text { land, a fee system, the system of parcels and } \\
\text { single goods, separately for pallets regardless } \\
\text { of the distance. } \\
\text { DP DHL: use of prices for the transport of } \\
\text { parcels at home and in the system of interna- } \\
\text { tional transport for the group with low prices } \\
\text { for parcels. }\end{array}$ & $\begin{array}{l}\text { DB Schenker: special prices for services offered } \\
\text { to key customers from automotive industry and to } \\
\text { institutional customers including the Metro Group. } \\
\text { DP DHL: special prices for B2C customers from } \\
\text { e-commerce sector, when managing the whole chain } \\
\text { of deliveries, contracts are signed. }\end{array}$ \\
\hline Personnel & $\begin{array}{l}\text { DB Schenker appreciates those with profes- } \\
\text { sional experience on each level of the organiza- } \\
\text { tion, both on white-collar positions, specialist } \\
\text { as well as operational position in terminals and } \\
\text { warehouses. The employees are offered a so- } \\
\text { cial package, private medical care and sports } \\
\text { classes. } \\
\text { DHL encourages each employee to undertake } \\
\text { initiative, become actively involved in various } \\
\text { teams and to achieve outstanding results. }\end{array}$ & $\begin{array}{l}\text { DB Schenker as an international leader in transport } \\
\text { and logistics, offers various positions of work adapt- } \\
\text { ed to graduates and experienced employees. } \\
\text { Deutsche Post DHL is a concern of a global and } \\
\text { multicultural nature that provides its services. The } \\
\text { supplier observes national rules and regulations re- } \\
\text { lated to working time, salaries and earnings as well } \\
\text { as employer benefits. }\end{array}$ \\
\hline Process & $\begin{array}{l}\text { DB Schenker offers shipments at home and } \\
\text { international shipments. In addition to this, it } \\
\text { proposes international transport by rail and it } \\
\text { organizes over-sized cargo shipments. } \\
\text { DP DHL offers help with an import and export } \\
\text { of consignments to the SME sector. It offers } \\
\text { logistics solutions for industry, e.g. delivery } \\
\text { chain management. }\end{array}$ & $\begin{array}{l}\text { DB Schenker focuses on solutions for various in- } \\
\text { dustries including pharmaceutical and automotive } \\
\text { industries or the industry of beverages and perish- } \\
\text { able goods. } \\
\text { DP DHL has created an international network. It } \\
\text { offers solutions related to parcels and express con- } \\
\text { signments worldwide, where the consignment can } \\
\text { be traced on a website. }\end{array}$ \\
\hline
\end{tabular}


Pobrane z czasopisma Annales H - Oeconomia http://oeconomia.annales.umcs.pl Data: 26/04/2023 12:41:34

\begin{tabular}{|c|c|c|}
\hline Instrument & Poland & Germany \\
\hline $\begin{array}{l}\text { Quality: } \\
\text { material } \\
\text { certificate }\end{array}$ & $\begin{array}{l}\text { DB Schenker possesses an Integrated Quality, } \\
\text { Environment and Labour Safety Management } \\
\text { System. } \\
\text { DHL Express (Poland) was the winner of the } \\
\text { Service Quality Emblem in the year 2011, in } \\
\text { the fourth edition of the Polish National Ser- } \\
\text { vice Quality Programme in the category of } \\
\text { courier services. }\end{array}$ & $\begin{array}{l}\text { DB Schenker is a member of the TAPA (Trans- } \\
\text { ported Asset Protection Association). It offers safe } \\
\text { storage solutions in over } 100 \text { selected locations in } \\
\text { the whole world. } \\
\text { In DHL, quality in logistics means zero errors in } \\
\text { batches, low product damage, timely order com- } \\
\text { pletion, high productivity and adaptation to cus- } \\
\text { tomer requirements as well as full compliance with } \\
\text { regulations. }\end{array}$ \\
\hline
\end{tabular}

Source: Author's own study on the basis of the websites of logistics operators: http://www.dpdhl.com/, http://www.dhl com.pl/pl, http://www.dbschenker.com/, http://www.dbschenker.pl/

On their websites, logistics operators emphasize social responsibility. They undertake issues of environmental protection on the global scale concerning carbon dioxide emissions, e.g. DP DHL: GoGreen or GoTeach programme that offers equal educational opportunities and employment prospects for young people in different parts of the world. The activeness of the users of urban areas, including operators, generates transport needs, which are reflected in the form of an increased traffic stream in the elements of the urban transport network [Chamier-Gliszczyński and Bohdal 2016, p. 670]. The achievement of a market success by logistics operators is possible owing to building a positive image. Obtaining competitive advantage is the objective of those companies that operative worldwide, like DP DHL and DB Schenker. From the marketing point of view, building a positive image is expected to result in more efficient and effective customer service on the part of logistics operators, who try to interact with customers through an appropriate mix of marketing instruments.

\section{Conclusions}

Logistics operators with global activities permanently analyze their marketing activities to acquire new market segments. When comparing the marketing composition in Poland and in Germany, differences are to be observed in each of the elements. Other services are preferred in the product depending on the country of operations, the price and distribution are adapted to the national determinants. Promotional policy is more widely implemented; in connection with this, the image is formed on the international market. In Poland, this is limited to personal sales and, to a small extent, to public relations. DB Schenker and DP DHL conduct worldwide charity events and they sponsor the German representation. TSL companies observe national regulations concerning working time, salaries and earnings as well as employer benefits: there is a social, medical and sports package for the whole concern, yet the pay and incentive system is separate for each country. The service provision process is adapted to the global network, yet material evidence is analyzed in the 
country where the head office is located, i.e. in Germany. In Poland, quality is perceived differently (through certificates), and in Germany it is perceived through error free cargo flow indexes. Logistics operators are perceived as global capital groups which operate on the Polish market. Their image is positive in spite of a different form of marketing-mix.

\section{Bibliography}

Byrne, P., Markham, W., Improving Quality and Productivity in the Logistics Process, Oak Brook, Butterfield Road 1991.

Chamier-Gliszczyński, N., Bohdal, T., Wskaźniki oceny mobilności miejskiej w aspekcie ochrony środowiska, "Annual Set The Environment Protection”, vol. 18, no. 1, 2016, pp. 670-681.

Ciesielski, M. (ed.), Rynek ustug logistycznych, Difin, Warsaw 2005.

Dyczkowska, J., Marketing ustug logistycznych, Difin, Warsaw 2014.

Gołembska, E., Logistyka w gospodarce światowej, C.H. Beck, Warsaw 2009.

Gołembska, E. (ed.), Kompendium wiedzy o logistyce, PWN, Warsaw 2010

Gołembska, E., Tyc-Szmil, K., Brauer, J., Logistyka w ustugach, PWN, Warsaw 2008.

http://www.dbschenker.com/ (access: 06.02.2017).

http://www.dbschenker.pl/ (access: 06.02.2017).

http://www.dhl.com.pl/pl (access: 07.02.2017).

http://www.dpdhl.com/ (access: 07.02.2017).

Lovelock, Ch., Service Marketing, Prentice Hall International, London 1996.

Łunarski, J., Zarządzanie jakością w logistyce, Wyd. Politechniki Rzeszowskiej, Rzeszów 2009.

Transport. Activity Results in 2015, Turek, D., Statistical Publishing Establishment, Warsaw 2016.

Żurawik, B., Żurawik, W., Zarządzanie marketingiem w przedsiębiorstwie, PWE, Warsaw 1996.

\section{Marketing of Logistics Services in Poland and in Germany}

The article covers marketing activities used by TSL companies. The purpose of the article was an analysis of marketing instruments on the market of logistics services in Poland and Germany. An analysis of literature and a comparative analysis of the services offered were used. The market of transport services in Poland was presented in comparison to selected European states. The elements of marketing realized in Poland and in Germany by the largest logistics operators and the image formed by them in both of these countries were presented. Their policy of social responsibility was emphasized in the article.

\section{Marketing usług logistycznych w Polsce i Niemczech}

W artykule zostały opisane działania marketingowe stosowane przez przedsiębiorstwa TSL. Celem opracowania była analiza instrumentów marketingu na rynku usług logistycznych w Polsce i Niemczech. Zastosowano analizę literatury i analizę porównawczą oferowanych usług. Zaprezentowano rynek usług transportowych w Polsce w porównaniu z wybranymi krajami europejskimi. Przedstawiono także elementy marketingu realizowane w Polsce i Niemczech przez największych operatorów logistycznych oraz kształtowany przez nich wizerunek w obu tych krajach. Ponadto zwrócono uwagę na prowadzoną przez nich politykę odpowiedzialności społecznej. 